Iryna Pashchenko ${ }^{1}$

\title{
ACTIVITIES OF THE PROSECUTOR'S OFFICE OF PODILIA IN 1922 - 1933 IN TERMS OF THE IMPLEMENTATION OF ITS FUNCTIONS
}

Keywords: New Economic Policy, prosecution agencies, legality, law order, functions, legal relations.

\begin{abstract}
The article studies the evolution process of the primary functions and the position of the prosecution agencies of Podilia in the '20s - the beginning of the ' 30 s of the XXth century in the government machinery at the stages of introducing the New Economic Policy (the NEP), its rolling back and holding a course for modernization of the industry. The author has carried out the retrospective analysis of the powers of the local prosecution agencies according to the statutory documents and acts approved by the party leadership, used substantive factual information on the activities of the Prosecutor's Office of the UkrSSR and its regional division - the Prosecutor's Office of Podilia.

It is essential to study the process of generation of the prosecution agencies in the UkrSSR, in particular, in Podilia in the '20s - the beginning of the ' 30 s of the XXth century, taking into account that they were one of the units of the system of organization of the Soviet society. Gradual strengthening of these agencies, granting them the extrajudicial powers and the increase of totalitarian pressure led to their direct subordination to the political regime of the Communist Party. The above highlights the importance to use the past historical experience to improve the legal and organizational fundamentals, identify the position of the Prosecutor's Office in the mechanism of modern independent Ukraine.
\end{abstract}

The study of regularities and principal trends of the development of the Soviet prosecution agencies, the search for alternatives to the authoritarian evolution of the state and prosecution agencies of Ukraine, as its inherent part, attach the socio-political importance to this issue. The

1 Lecturer at the Cycle Commission of Social Disciplines and Jurisprudence, Vinnytsia College of Trade and Economics of Kyiv National University of Trade and Economics, pashchenko19@ukr.net. ORCID: 0000-0002-3056-5438 
public consciousness has still kept a cursory view of the law enforcement system of the UkrSSR of the ' $20 \mathrm{~s}$ - the early ' 30 s of the XXth century. Thus, a thorough examination of the process of development of prosecution agencies, in particular, in Podilia, contributes to answering many questions of the present, allows avoiding mistakes during the implementation of the actual reforms in the Prosecutor's Office of Ukraine. In the modern context, the realization of a European civilization choice by Ukraine is impossible without reforming the judicial system, including the Prosecutor's Office, relating to the discussion of the relevant draft laws.

The establishment of the Prosecutor's Office as a body of the "revolutionary legality" fully met needs of the party, which stimulated the organizational structure of the law enforcement system of the Soviet society and assigned leadership to the Prosecutor's Office. It is possible that in the other scenario, the functions of the state prosecution, investigation and surveillance would not be performed by one person, but repressive-punitive character of the policy promoted the origin of the Prosecutor's Office just as it was operating for a long time.

\section{INTRODUCTION}

The scientific novelty of the research is in the fact that it is a pioneer complex study in modern historiography concerning the development of the prosecution agencies of the UkrSSR in Podilia in 1922 - 1933. For the first time in the scientific context, the author uses a significant number of documents from the central and local archives, which are a basis for her generalizations and estimations included in the research text; analyses historical conditions and features of the formation of prosecution authorities of Podilia.

The evolution of the government machinery which was manifested in the establishment of the strict totalitarian regime in the late '20s of the XXth century in the USSR and the UkrSSR, as its constituent part, directly affected the organization and essence of the activities of the Prosecutor's Office; the performance of a punitive function was a priority, and general supervision over legality as well as over the legality of judicial and investigative activities became secondary, subordinate; it was intended to control the observation of laws - at the beginning of the ' 30 s, the prosecution agencies not only indulged in illegal actions of other "law enforcement" agencies but also allowed illegal actions (start of mass terror, inspiration of lawsuits, etc.) on the instructions of the leadership of the Bolshevik Party. 
Activities of the local Prosecution Office in the NEP period (1922 - the beginning of 1929) were focused on the exercise of the objectives of the New Economic Policy, balancing relations between the center and localities; in the following period, the organizational function of the role of the Prosecutor's Office in the government machinery decreased - its activities were aimed at destroying "enemies of the people", "saboteurs", solving production assignments (industrialization, collectivization).

The establishment of the strict totalitarian regime in the late '20s of the XXth century in the USSR and the UkrSSR, as its constituent part, directly affected the organization and essence of the activities of the Prosecutor's Office; the performance of a punitive function was a priority, and general supervision over legality as well as over the legality of judicial and investigative activities became secondary, subordinate.

\section{THE RELEVANCE OF THE RESEARCH}

The study of the history and challenges of developing the prosecution authorities in the UkrSSR during 1922 - 1933 is of practical and scientific significance in the contemporary period of reforming the Prosecution's Office of Ukraine and an important mission of historical science.

The Constitution of Ukraine defines the Prosecutor's Office as a single system. The statement of the basic framework on the Prosecutor's Office in the separate section of the fundamental law gives grounds to confirm that the execution of functions and powers entrusted to the prosecution agencies as well as the nature of actions of the Prosecutor's Office and principles of their organization are an independent type of the state activity.

To solve the tasks set before the Prosecutor's Office, it must use the best traditions of scientific, methodological heritage and organizational experience of ensuring the rule of law in the context of building the civil society in Ukraine. One of the burning issues, which is a center of the discussion about the position and role of the prosecution agencies in the modern state mechanism of Ukraine, is general (supreme) control. It is a determinative when forming the relations of the Prosecutor's Office not 
only with the actors of judicial proceedings, preliminary investigation, inquiry, operational and investigative activities (i.e. with judicial and law enforcement agencies) but with all bodies, enterprises and institutions that together interact and constitute the mechanism of the state.

Thus, the relevance of the research is stipulated by the need to solve such vitally-important tasks for Ukraine as the creation of the prosecution institute which is more effective and recognized by the population, the system with the priorities of the Prosecutor's Office in favor of the protection of constitutional rights and freedoms of a man and a citizen which primarily corresponds to the idea of the formation of the rule-of-law state.

Despite some administrative, bureaucratic and legislative obstacles, the system of prosecution bodies of the democratic pattern is being renewed. The expediency of the reforms of the Prosecutor's Office in the period of Ukraine's independence, specifically in recent years, has been beyond doubts. The controversies about reforming the institute of the Prosecutor's Office led the scientists to refer to the course and outcomes of the evolution and development of the prosecution agencies of the UkrSSR in the '20s of the XXth century. The formation of a system of activities of the Prosecutor's Office based on the democratic principles of building the rule-of-law state allows using positive transformations of those years by giving up on the forms, methods and principles of work inherent in the totalitarian regime. A tragic experience of the second part of $1920-1930$ s warns modern reformers not to repeat the mistakes of the past, encourages the search for effective ways of reforming the prosecutor's office.

The purpose of this research is to elucidate the evolution process of the basic powers and functions of the prosecution agencies using the example of Podilia region, their classification in the system of public administration in the period of its establishment. The purpose is realized through such research tasks: to present the state of scientific examination of the problem, its source base and research methodology; to determine the position of the Prosecutor's Office in the system of law enforcement agencies of the USSR; to investigate the historical conditions of the formation of the prosecution agencies in Podilia; to characterize the powers of the prosecution agencies using the example of Podilia region; to analyze the activities 
of the prosecution agencies of Podilia in terms of the implementation of their functions.

\section{RESEARCH METHODOLOGY}

The article uses the general scientific, special-historical and interdisciplinary methods. The general-scientific ones involve statistical technique, search, analysis, synthesis, description. In the context of the examination of the multi-faceted sources, their application has contributed to the reproduction of the real facts of the period under study. Based on the statistical method, the qualitative and quantitative indicators, which relate to the prosecution agencies, are analyzed. Methods of theoretical analysis and synthesis have made it possible to determine the objective patterns of the development of the system of prosecution agencies and identify the interrelationship of their components.

The problem-chronological method allows tracing the dynamics of the socio-political phenomena under investigation. The system method is predominant for the study of the history of prosecution agencies of Podilia in 1922 - 1933 because the Prosecutor's Office is considered as an essential element of the state mechanism, which played a crucial role in executing the instructions of the Soviet political leaders.

The historical method, which provides for the examination of all scientific facts inextricably linked to the past, present and future, is no less important for the scholarly research. Thus, the study of the history of reforming and activities of the prosecution agencies is a necessary condition for the understanding of their current status and forecasting the development in the independent Ukraine.

In terms of the cognitive activity, all the above methods are interconnected, complementary. Together, they make it possible to examine sources, master the available literature, systematize and generalize data obtained, guarantee the scientific reliability of findings. 


\section{POWERS OF THE PROSECUTOR'S OFFICE ACCORDING TO NORMATIVE ACTS}

The issue of powers is of great importance for the operation of any chain, element of the state mechanism, the main factor in the performance of entrusted duties. Taking into account the above, the Bolsheviks tried to define the functions of newly created prosecution agencies in details that would considerably determine the effectiveness of their practical activities in the future.

For this very reason, fierce disputes among the Bolsheviks on the principles of functioning of the Prosecutor's Office preceded the approval of the Decision of VTsIK of the RSFSR (the All-Russian Central Executive Committee), which adopted the Regulations “On the Prosecutor's Supervision". Thus, on May 12, 1922, the Third Session of VTsIK of the RSFSR considered the implementation of revolutionary legitimacy under the assistance of prosecution agencies. At the same time, it was sparked sharp controversies due to a report of the government and party leader M.V. Krylenko, who treated Prosecutor's Office staff as investigation managers - people who were empowered to prevent crime and conduct the state control over the legality of acts of citizens and government bodies. $\mathrm{He}$ proposed to establish the public prosecution service independent of the bodies which can influence the exercise of powers and appealed to release it from the affection of guberniyas' executive committees (Krylenko, 1992, p. 5).

Whereas, Chairman of VTsIk of the USSR M. I. Kalinin supported the idea to appoint prosecutors from the centre. In his opinion, being invested with special powers realized through subordinate guberniya prosecutors, such persons would be "an eye of the center". Guberniya Prosecutor's Office as a body which implements the revolutionary legality on the spot should be free of guardianship of the guberniya executive committee (Kalinin, 1922, p. 6).

People's Commissar of Justice of UkrSSR M. O. Skrypnyk highlighted when supporting "centrists": “...if to establish the Prosecutor's Office subordinated to the guberniya executive committee (gubvykonkom) for challenging and supervising activities of the guberniya executive commit- 
tee, there is no need to open the ball. We need the Prosecutor's Office because a bunch of individual regulations rendered by gubvykonkoms elucidates a necessity to adhere to a unified practice across the whole republic (Skrypnyk, 1922, p. 54).

The Regulation "On Prosecutor's Supervision in the UkrSSR" approved by VUTsVK as of June 28, 1922 didn't specify the powers and focus areas of the prosecution agencies and just characterized individual components. The very title of the statutory document highlights the primary function of the Prosecutor's Office - "to supervise the legality on behalf of the state". At the same time, its provisions included the obligations imposed on the Prosecutor's Office by the Soviet authorities. They initially referred to administrative and judicial control: to supervise the legality of actions of all authorities, economic institutions, public and private organizations and individuals by initiating criminal proceedings against the perpetrators and protesting against decisions that violated the law; direct supervision over the activities of bodies of inquiry and investigation in the field of exposure of crime as well as of the State Political Administration (DPU); to handle the prosecution in court; to control the propriety of detention of prisoners; to supervise the activities of juvenile commissions (Vestnik Sovetskoy Justicii, 1922, p. 43).

At the moment of the introduction of the Regulation "On Prosecutor's Supervision in the UkrSSR", the republic was divided into guberniyas, povits, and volosts in the administrative-territorial context. It is clear that the main workload of the local Prosecutor's Office was entrusted to guberniyas' prosecutors. They were authorized to lodge a motion to the executive committees on the cancellation or alteration of orders and resolutions inconsistent with the law issued by them or their subordinate bodies and to appeal against the above-mentioned orders and resolutions through the Prosecutor of the UkrSSR in the CPC (the Council of People's Commissars) or the Presidium of VUTsVK (Vestnik Sovetskoy Yustitsii, 1922, p. 44). When exercising the powers, a prosecutor submitted a report on the performance outcomes of the Prosecutor's Office on the spot, as well as of his direct activity and his assistants, to the Prosecutor of the Republic every three months. Thus, it was emphasized that the key areas of the activities of the Prosecutor's Office laid the main organizational 
principle of their composition - a clear centralization of the structure from top to bottom.

The Regulation also defined some forms of administrative supervision as an inherent element of the general (supreme) control. The Republic's Prosecutor as well as guberniyas' prosecutors were authorized to be present at all sessions of the local executive committees with the right of a consultative vote (art. 11) (Vestnik Sovetskoy Yustitsii, 1922, p. 44). The special instruction for guberniyas' prosecutors "On the Procedure of Administrative Supervision" stipulated the procedure of administrative supervision at the local level in more details. Whereby, the Republic's Prosecutor controls the activities of guberniyas' prosecutors. It states the following: "In the effort to penetrate the whole administrative life of a guberniya, some guberniyas' prosecutors ... issued the orders on their registration of all agreements concluded by the government establishments and enterprises, on the provision them with copies of all departmental orders, instructions etc., on the sending of a schedule of sessions to the office of guberniya's prosecutor etc. Such a broad interpretation of the functions of administrative supervision would load a lot of work on the prosecutor's apparatus..., would make it impossible for the Prosecutor's Office to exercise its direct tasks" (Biuleten Narodnoho komisariatu yustytsii USRR, 1922, p. 141).

A judicial reform preceded the process of establishing the prosecution agencies. On December 16, 1922, VUTsVK approved "The Regulation on the Judiciary of the UkrSSR" which specified that the Prosecutor's Office carries out supervision over the general compliance with the laws and direct supervision of the preliminary investigation and inquiry, support of the prosecution in court (Zbirnyk postanov ta rozporiadzhen robitnyche-selianskoho uriadu Ukrainy, 1922, p. 247). 


\section{THE PERFORMANCE OF ADMINISTRATIVE SUPERVISION BY THE LOCAL PROSECUTOR'S OFFICE}

The party extensively tried to control the staff of the Prosecutor's Office. For a successful implementation of that task, guberniyas' committees received monthly reports of a guberniyas prosecutor at the sessions. However, guberniyas' committees didn't impede the operation of prosecution agencies in terms of the termination, prevention and solution of crimes regardless of the party or official affiliation of defendants. In this context, the activities of the prosecution agencies should meet the unanimous assistance and support. If guberniya Prosecutor's Office and guberniya committee were divided over solving cases, the latter didn't interfere with a prosecutor's actions but addressed the Central Committee of the Communist Party of the Soviet Union (TsK RKP) for deciding controversial issues. Moreover, TsK RKP obliged the Secretary of guberniya committee to provide characteristic of the guberniya prosecutor, account to TsK RKP on disputes in their activities, mark specific features of the prosecutor's oppositions to the decisions of the local authorities (Derzhavnyi arkhiv Vinnytskoi oblasti, 1923, p. 54).

Thus, during the fledging years of the Soviet Prosecutor's Office, there was a search for specific forms and methods of supervision in various areas of its work. Prosecutors used the following forms in the context of administrative supervision: preliminary coordination of draft regulations of People's Commissariats, departments, executive committees and their departments with prosecutors; review of issued regulations by a prosecutor; the prosecutor's participation in the sessions of the executive committees of the local councils; inspection of institutions and enterprises. Oppositions, regulations and proposals of the prosecutor were the forms of his response to the detected offences. Thus, in 1923 the local prosecution agencies challenged 642 regulations of the guberniya gubvykonkoms, including Podilia Guberniya Prosecutor's Office - 134 (Derzhavnyi arkhiv Vinnytskoi oblasti, 1923, p. 54).

A limited number of protests made by the guberniyas' prosecutors is explained by the fact that the method of preliminary revision of mandatory regulations was widely practiced that made it possible to amend 
projects promptly and prevent the issuance of illegal regulations (Falkevych, 1924, p. 137).

Another way to implement the supervisory function in the '20s of the XXth century was a reaction of the Prosecutor's Office to statements and complaints from Soviet agencies and citizens - the core indicators of the public mood. Analyzing the issue of citizen appeals, it is expedient to cover the subject matter of the appeals through Podilia region. Their bulk concerned the issues of illegal imposition of taxes by local financial bodies and village executive committees, illegal determination of rural tax categories. A considerable part of complaints received by the guberniya Prosecutor's Office regarded the violations of decrees, instructions, orders on the provision of tax benefits to poor peasants, families of Red Army soldiers, people with disabilities, rural artisans prescribed by the Regulation "On the Unified Agricultural Tax" as of April 30, 1924; Instruction of the People's Commissariat for Finance of the USSR (NKF SRSR) "On Agricultural Tax" as of June 7, 1924; Instruction "On the State Income Tax" (Sbornik nalogovogo zakonodatelstva, 1925, p. 156). Thus, assistant of the Guberniya Prosecutor of Podilia I. S. Yassan stated that by issuing the instructions, the guberniya Prosecutor's Office drew attention to the need to pursue a hard line in the fight against taxation, which was of local nature, and was not regulated by the tax legislation. The imposition of "local" taxes, voluntary donations usually required forced taxation, especially in volosts and villages. In particular, in the former Zhmerynka povit, the local volost budget was based on desiatina taxation of the peasantry. Such manifestations disrupted the policy of the Soviet government in terms of the elimination of class controversies and demolished the agricultural industry to raise the productivity of which the government of those days made fierce efforts. The fight against the "local" nonstatutory taxes was of great political importance (Derzhavnyi arkhiv Vinnytskoi oblasti, 1925, p. 25).

The correlation of the number of complaints from different social groups concerning individual crimes or types of wrongful acts is characterized by the table below (Falkevych, 1925, p. 3-4). 
Table 1. The correlation of the number of complaints from different social groups concerning individual crimes or types of wrongful acts is characterized by the table below

\begin{tabular}{|c|c|c|c|c|c|c|}
\hline \multirow[b]{2}{*}{ CRIMES } & \multicolumn{6}{|c|}{$\begin{array}{l}\text { Proposals to bring to justice expressed in } \\
\text { complaints of }\end{array}$} \\
\hline & 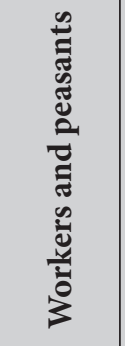 & $\begin{array}{l}\frac{\mathscr{a}}{\tilde{J}} \\
\stackrel{\tilde{U}}{0} \\
0\end{array}$ & 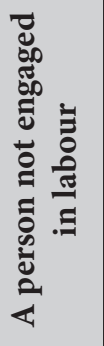 & $\begin{array}{l}\infty \\
\infty\end{array}$ & 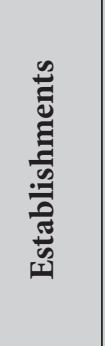 & 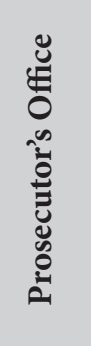 \\
\hline 1. Abuse of power & 6,87 & 7,02 & 2,86 & 23,63 & 6,34 & 3,85 \\
\hline $\begin{array}{l}\text { 2. Exceeding the official powers } \\
\text { and inactivity of the authorities }\end{array}$ & 28,68 & 27,19 & 25,71 & 21,43 & 27,05 & 29,67 \\
\hline $\begin{array}{l}\text { 3. Negligence of the official obli- } \\
\text { gations }\end{array}$ & 1,45 & 1,75 & 1,43 & 30,77 & 12,87 & 4,40 \\
\hline 4. Discreditation of authorities & 4,58 & 7,02 & 7,14 & 9,34 & 4,10 & 3,30 \\
\hline $\begin{array}{l}\text { 5. Illegal arrests, coercion to } \\
\text { testify }\end{array}$ & 23,37 & 15,79 & 35,72 & 0,55 & 9,52 & 21,42 \\
\hline $\begin{array}{l}\text { 6. Misappropriation or dissipa- } \\
\text { tion of another's property }\end{array}$ & 15,90 & 19,30 & 1,43 & 5,50 & 21,46 & 18,13 \\
\hline 7. Corruption & 10,36 & 9,65 & 7,14 & 3,84 & 9,52 & 21,42 \\
\hline 8. Official counterfeits & 4,81 & 3,51 & 5,71 & 1,10 & 4,85 & 2,20 \\
\hline 9. Other official crimes & 3,98 & 8,77 & 12,86 & 3,84 & 4,48 & 1,65 \\
\hline
\end{tabular}

Sources: Falkevych, 1925, p. 3-4.

The data in the table show that in terms of percentage scope, cases of abuse of power were mostly marked by the press and unemployed groups of the population in insignificant amounts (23.63\%). Such a crime as exceeding of the official powers and inactivity of the authorities was traced in the complaints of all social categories with equal intensity. Press claims directly accusing officials of negligence took a third (30.77\%). More than a third of the appeals from the unemployed population groups and almost a quarter of the peasants complained about the illegal restriction of liberty. 
The establishments (21.46\%) and officials (19.30\%) more often accused of the official appropriations and wasteful spending. Peasants (10.36\%), civil servants $(9.65 \%)$ and non-labor groups (7.14\%) frequently complained about the corruption practices. When analyzing the cases which were directly initiated by the Prosecutor's Office, it is worth mentioning that exceeding the official powers and inactivity of the authorities held the top spot among others, illegal arrests came second, misappropriation and dissipation of another's property - third, and corruption - fourth (Falkevych, 1925, p. 4-5).

The message of the appeals lodged by the social groups contained different accusations of illegal actions of officials. In particular, workers and peasants complained about the illegal seizure of property, including the withdrawal of agricultural equipment, land and buildings (21.31\%), taxation (10.88\%), the imposition of administrative fines (7.71\%). Almost half of all complaints of the officials concerned illegal eviction of the population (46.13\%), seizure of property (19.20\%). Among the "non-labor elements", complaints of illegal imposition of fines $(22.50 \%)$ were first, eviction - second (19.10\%). The next indicators were distributed as follows: seizure of property (16.18\%), taxation (15.30\%), nationalization of buildings $(9.73 \%)$. In the context of taxation and collection of fines through administrative proceedings, the complaints of "unemployed elements" amounted to $15.30 \%$ and $22.50 \%$ respectively and of peasants and workers $-10,88 \%$ and $7,71 \%$; the least indicators were shown among officials: $5.05 \%$ and 6.73 . However, the opposite situation was typical for complaints about the delay in initiating cases by the prosecution agencies: workers and peasants $(4.77 \%)$, employees (1.68\%) and non-labor groups (0.51\%) (Falkevych, 1925, p. 4).

\section{THE COOPERATION OF THE LOCAL PROSECUTOR'S OFFICE WITH VILLAGE CORRESPONDENTS}

When following the instructions of the party leadership, the Prosecutor's Office had to control that the fight against crime was held with the direct engagement of the working classes. Newspaper paragraphs of the 
village correspondents were an import source for the detection of the violations of the public order (banditry, hooliganism) by the local Prosecutor's Office under the framework of general supervision. The topics of press reports due to which the Prosecutor's Office initiated investigation were quite diverse: speculation, rising prices for goods and products, bribery, red tape, bureaucracy, wasteful expenditure and embezzlement of money and property, attempted assassination of village correspondents, etc. The materials from Vinnytsia District Prosecutor's Office confirm that the posts of the worker and village correspondents greatly affected the improvement of the operation of the local establishments and enterprises. From October 1, 1925 to August 1, 1926, the District Prosecutor's Office registered 481 newspaper articles. The majority of these articles (67\%) mainly belonged to the local periodicals: "Chervonyi krai" and "Vinnytska robitnycha hazeta". It should be noted that first of all, the employees of the District Prosecutor's Office examined the items concerning the life and work of the lower Soviet apparatus - $24.3 \%$, local cooperation - $11 \%$, state enterprises (sugar and brick factories) $-14.3 \%$. The above facts prove that the worker and village correspondents helped the prosecution agencies to find out the manifestations of mismanagement, bureaucracy in the system of public administration that was typical for the activity of local agencies (Chervonyi krai, 1926, p. 3).

In the late '20s - the early 30 's, the tendency to centralize the whole public administration, limit the sovereignty of the republics in favor of the union center strengthened. During the formation of the totalitarian regime in the Soviet Union, the Regulation "On the Establishment of the Prosecutor's Office of the USSR" dated June 20, 1933 approved by the TsVK and CPC of the USSR (Code of Laws of the USSR, 1933, p. 241). According to "the Regulation on Prosecutor's Office" as of December 17 of the same year (Code of Laws of the USSR, 1933, p. 357), remaining the part of the People's Commissariat of Justice from the formal and organizational point of view, the Prosecutor's Office of the UkrSSR (like most other union republics) was, in fact, strictly subordinated to the centralized Prosecutor's Office of the USSR. 


\section{CONCLUSIONS}

As a result, the study of the functions of the Prosecutor's Office and methods of their implementation shows that the Bolsheviks created a system of the prosecutor's supervision maximally adjusted to the government and political order of the UkrSSR. The formation of the Prosecutor's Office as a body of the "revolutionary legality" fully met the needs of the party, which stimulated the organizational system of the law enforcement system of the Soviet society and granted the Prosecutor's Office the role of leader. That state of affairs led to the fact that the Prosecutor's Office turned into a mobile and disciplined tool not only for the supervision but also for total control of almost all public relations. Analyzing the interaction of local prosecution agencies with the authorities in the late ' 20 s - early 30 's, one can trace how, obeying the line to counteract the escalation of class struggle in the course of the building of a socialist society, they increasingly shifted the burden of their work from the general supervision to punitive activities and participation in criminal proceedings.

\section{BIBLIOGRAPHY:}

Dva hoda deiatelnosty prokuraturb USSR. Otchetnыi doklad Prokurora respublyky na IV-oi sessyy VUTsYK VIII-ho sozbva (1925) [Two years of activity of the Prosecutor's Office of the USSR. Report of the Prosecutor of the Republic at the IVth session of VUTSIK of the VIII convocation]. - Kharkov.

Derzhavnyi arkhiv Vinnytskoi oblasti [State archive of Vinnytsia oblast]..

Edynui selskokhoziaistvennыi naloh 1925-26 h. Sbornyk nalohovoho zakonodatelstva (1925) [Unified agricultural tax of 1925-26. Collection of tax legislation]. Moscow: Fynansovoe yzdatelstvo NKF SSSR.

Narodnyi komisariat yustytsii (1924) Zbirnyk uzakonen ta rozporiadzhen robitnychoselianskoho uriadu Ukrainy za 1924 rik. Pro nadannia pilh chervonoarmiiskym rodynam pry podanni skarh na nepravylne opodatkuvannia yedynym s/h podatko [Collection of regulations and orders of the workers and peasants government of Ukraine for 1924. On granting benefits to Red Army families when filing complaints about incorrect taxation by the single agricultural tax]. Kharkiv: Drukarnia UVO im. M. Frunze. 
Narodnyi komisariat yustytsii URSR (1922) Zbirnyk postanov ta rozporiadzhen robitnyche-selianskoho uriadu Ukrainy [Collection of orders and instructions of workers' and peasants' government of Ukraine]. Kharkiv: Druk. "Vukopspilky".

Narodnyi komisariat yustytsii (1924) Zbirnyk uzakonen ta rozporiadzhen robitnychoselianskoho uriadu Ukrainy za 1924 r. [Collection of regulations and orders of the workers and peasants government of Ukraine for 1924]. Kharkiv: Drukarnia UVO im. M. Frunze.

Rada Narodnykh Komisariv URSR (1925) Zbirnyk uzakonen ta rozporiadzhen robitnycho-selianskoho uriadu Ukrainy za $1925 \mathrm{r}$. [Collection of regulations and orders of the workers and peasants government of Ukraine for 1925] Kharkiv: Drukarnia PU UVO im. M. Frunze

Zvit pro diialnist NKIu URSR za 1923 - 1924 (1925) [Report on the activities of the NKVD of the USSR]. Kharkiv.

Zdysh A. (1930) Za chitke vykonannia partiinoi linii [For clear implementation of the party line]. Visnyk radianskoi yustytsii, No. 9.

All-Ukrainian Central Executive Committee (1922) Polozhenye o prokurorskom nadzore [Regulations on prosecutorial supervision]. Vestnyk Sovetskoi Yustytsyy, No. 5-7.

People's Commissariat of Justice of the USSR (1922) Pro poriadok zdiisnennia administratyvno dohliadu. Obizhnyk do vsikh hub prokuroriv [About the order of implementation of administrative supervision. Instruction for all guberniya prosecutors]. Biuleten Narodnoho komisariatu yustytsii USRR, No. 17.

Protesty administratyvnoho dohliadu Prokuratury USRR z pryvodu postanov ta rozporiadzhen orhaniv vlady (1926) [Protests of administrative supervision of the Prosecutor's Office of the USSR against the decisions and orders of the authorities]. Kharkiv.

Code of Laws of the USSR (1933), No. 40, Art. 239.

Code of Laws of the USSR (1933), No. 55, Art . 324.

Silkory - pomichnyky prokuratury (1926) [Village correspondents - assistances of the Prosecutor's Office]. Chervonyi krai, No. 48.

III sessyia Vserossyiskoho Tsentralnoho Yspolnytelnoho Komyteta IX sozыva (12 - 27 maia 1922 h.): [Stenohrafycheskyi otchet] [III Session of the All-Russian Central Executive Committee of the IX convocation (May 12-27, 1922) [Stenographic report]]. Moscow: Yzdanye VTsYK.

III sessyia Vserossyiskoho Tsentralnoho Yspolnytelnoho Komyteta IX sozыva (20 maia 1922 h.) [III session of the All-Russian Central Executive Committee of the IX convocation (May 20, 1922). Moscow: Yzdanye VTsYK.

Falkevych I. D. (1924) Administratyvnyi nahliad prokuratury URSR [Administrative supervision of the UkrSSR Prosecutor's Office]. Visnyk radianskoi yustytsii, No. 5- 6. Falkevych I. D. (1925) Administratyvnyi nahliad prokuratury URSR [Administrative supervision of the UkrSSR Prosecutor's Office]. Visnyk radianskoi yustytsii, No. 1. 